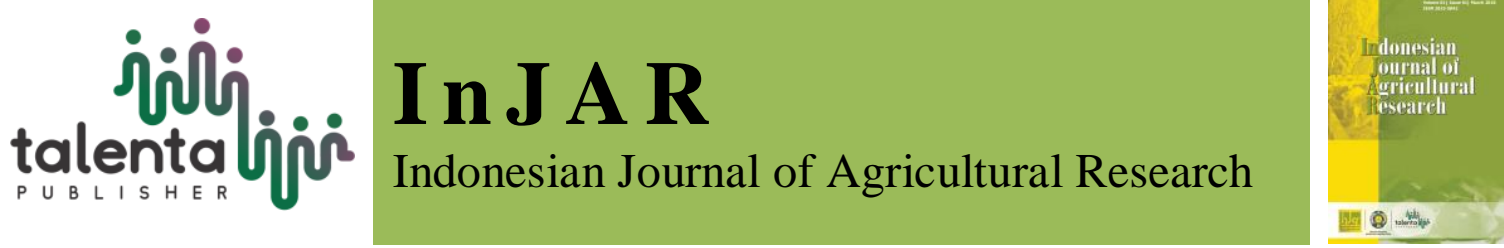

\title{
Palatability Test of Mineral Herbal Blocks on Performance of Local Sheep
}

\author{
Aisyah Nurmi and Muharram Fajrin Harahap \\ Faculty of Animal Husbandry, Universitas Muhammadiyah Tapanuli Selatan (UM Tapsel), \\ Padangsidimpuan, Indonesia
}

\begin{abstract}
This research was aimed to study of palatability and body weight gain local sheeps given minerals herbal $(\mathrm{MBH})$. The farms used in this study were male 4 local sheep at the age of 12-18 months who showed symptoms of mineral deficiency. The research method used is the Latin Square Design (LSD). The treatment given is: H0 = Basal Feed + Salt H1 = Basal Feed + Salt + Mineral + Turmeric $;$ H2 = Basal Feed + Salt + Mineral + Ginger; $\mathrm{H} 3=$ Basal Feed + Salt + Mineral + Turmeric + Ginger. The research parameter is the mineral palatability of herbal blocks and body weight gain. The results showed that $\mathrm{MBH}$ given turmeric (10\%), ginger (10\%) and a combination of 5\% +5\% ginger showed a non-significant effect on feed consumption and conversion. Palatability test showed that all $\mathrm{MBH}$ treatments were favored by local sheep, but the highest palatability of MBH was by adding ginger; followed by a combination of ginger and turmeric; and the lowest palatability is turmeric. Based on palatability tests, $\mathrm{MBH}$ with turmeric supplementation of $10 \% ; 10 \%$ ginger or a combination of $5 \%$ ginger $+5 \%$ turmeric in the form of Herbal Minerals Block has a good palatability (preferred) and can improve the performance of local sheep
\end{abstract}

Keywords: herbal, minerals, palatability, sheeps

Received 08 April 2019| Revised 17 May 2019| Accepted 13 August 2019

\section{Introduction}

Sheep needs nutrients such as carbohydrates, proteins, vitamins and minerals. Nutrition is actually already contained in a feed. It's just that for certain nutrients such as minerals there are very few in number. Therefore, farm experts advise in feeding sheep with a variety of feed ingredients. The goal is that lack of nutrients in one material can be covered by other ingredients and complement each other. To be able to grow and develop optimally, sheep must be fulfilled by their mineral needs. Lack of minerals in sheep can cause serious problems; sheep experience weight loss, loss of appetite, thinness, decreased endurance, late lust, young people are born with weak conditions, low milk production, miscarriages, and paralysis.

\footnotetext{
*Corresponding author at: Faculty of Animal Husbandry, Universitas Muhammadiyah Tapanuli Selatan (UM

Tapsel), Padangsidimpuan, 22716, Indonesia

E-mail address: aisyah.nurmi@um-tapsel.ac.id
} 
To prevent the occurrence of mineral deficiencies in livestock, it is necessary to provide additional minerals in sheep. Giving minerals can pass combos, drink, or put in bottles and hang in a cage. Mineral products for livestock have also been found on the market. In order to provide more practical and efficient minerals, minerals are given in the form of block minerals. Mineral blocks are minerals that are mixed with hardener and then minerals are printed and become solid or hard. With a solid texture, minerals will be licked according to their needs. The requirement is the mineral block must be placed or hung in a cage and can be reached by livestock

\section{Materials and Methods}

\subsection{Experimental Location, Source and Processing}

The study was conducted at the Faculty of Animal Husbandry, South Tapanuli Muhammadiyah University, Padangsidimpuan, North Sumatera. The material used in this research to be used are 4 male local sheep. The adaptation period for sheep that will be treated is carried out. The feed used in this study is basal feed (field grass obtained around the cage and concentrate consisting of rice bran) + minerals according to treatment; with a ratio of 70:30, drinking water is given ad-libitum and worm medicine (kalbazen) given orally at the beginning of maintenance to prevent worm disease in local sheep.

\subsection{Experimental Design}

This study was designed using a Latin Square Design (LSD) which consisted of four (4) combinations of treatments as rows and four (4) periods as columns. The treatment used in this study is feed with a different composition, where: H0 = Basal Feed + Salt; H1 = Basal Feed + Salt + Mineral + Turmeric; H2 = Basal Feed + Salt + Mineral + Ginger; H3 = Basal Feed + Salt + Mineral + Turmeric + Ginger. The variables observed were $:$ average daily gain, feed consumption, and feed conversion ratio. The experiment was conducted for The variables observed were: daily body weight gain, feed consumption, and feed conversion ratio. The experiment was carried out for 7 weeks with a length of 1 week period and rest 1 week before the next period, beginning with the adaptation period of 2 weeks. The experimental diet composition for the experiment (Table 1).

Table 1. Composition of the experimental diets

\begin{tabular}{ccccc}
\hline \multirow{2}{*}{ Materials } & \multicolumn{4}{c}{ Treatment } \\
\cline { 2 - 5 } & H0 & H1 & H2 & H3 \\
\hline Ultra minerals & 0 & 20 & 20 & 20 \\
NaCl & 100 & 60 & 60 & 60 \\
Cement & 0 & 10 & 10 & 10 \\
Turmeric & 0 & 10 & 0 & 5 \\
Ginger & 0 & 0 & 10 & 5 \\
\hline
\end{tabular}




\section{Result and Discussion}

\subsection{Palatability of Mineral Herbal Blocks (MBH)}

This palatability is seen from how much MBH is eaten. Palatability test for the four MBH treatments to determine the level of palatability was done by measuring the consumption of $\mathrm{MBH}$. The results showed that the treatment $\mathrm{H} 2 ; 10 \%$ ginger had the highest level of palatability (preferably) followed the $\mathrm{H} 3$ (5\% turmeric $+5 \%$ ginger) then treated as control (H0) and finally the $\mathrm{H} 1 ; 5 \%$ turmeric. The results showed that mineral block herbal did not significantly effect $(\mathrm{P}>0.05)$ to the feed consumption and feed conversion. Effect of $\mathrm{MBH}$ on ration in the significantly $(\mathrm{P}<0.05)$ on average daily gain of local sheep. Giving $\mathrm{MBH}$ in local sheep there is no negative effect on palatability and weight gain. Chemical and physical properties of old turmeric rhizome turmeric contains several components including essential oils, pigments, fats, bitter substances, resins, proteins, pentose cellulose, starch, mineral elements and so on. The main component is starch which ranges from $40-50 \%$ dry matter. The content of turmeric varies depending on the cultivar growth area as well as pre-harvest and postharvest conditions [1]. The orange yellow color of turmeric is caused by a derivative of diferuloyl methane which does not evaporate by heating, where curcumin is the dominant compound. The curcuminoid pigment is a substance consisting of a mixture of curcumin (the most dominant) compounds, desmetoxycurcumin and bisdesmetoksikurkumin [2]. The aroma and taste of turmeric is determined by the content of essential oils which evaporate by heating [1]. Essential oil is a liquid substance that is contained in plant or animal simplexis and smells good [2]. That essential oils in turmeric contain three main components, including oxygenated sesquiterpen, sesquiterpen hydrocarbon and oxygenated monoterpenes [1]. Various studies show that the main component of turmeric essential oil is an alcohol with the formula C13H18O18 which is then called turmenol.

In general, when viewed from the physical form of the herbal block minerals produced it has a more brittle texture compared to the mineral blocks whose composition is general or original (mineral + cement + salt + bran). This is due to the binding power of the water produced by evaporation of salt which cannot be absorbed by the mineral-forming ingredients, which in the original mineral composition water absorption is aided by the use of bran, thereby reducing the corrosion properties of the resulting mineral block. The physical form of herbal block minerals that tend to be tender causes a high level of palatability, based on sequential palatability tests of the highest palatability in ginger MBH 10\%, then MBH (5\% ginger $+5 \%$ turmeric) and lowest $5 \%$ turmeric $\mathrm{MBH}$.

\subsection{Effect of Treatment on Performance}

Feed given to livestock is one of the factors that influence growth. The livestock will reach the highest level of appearance in accordance with their genetic potential if they obtain needed food substances [3]. 
Table 2. Average Daily Gain, Consumption and Feed Conversion of local sheeps (g/head/day)

\begin{tabular}{|c|c|c|c|c|}
\hline \multirow{2}{*}{ Parameters } & \multicolumn{4}{|c|}{ Treatments } \\
\hline & Ho & H1 & H2 & H3 \\
\hline $\begin{array}{l}\text { Average Daily Gain } \\
\text { (g/head/day) }\end{array}$ & $23.00 \pm 4.24^{\mathrm{a}}$ & $24.25 \pm 3.095^{\mathrm{ab}}$ & $24.63 \pm 3.30^{\mathrm{ab}}$ & $25.55 \pm 3.30^{\mathrm{b}}$ \\
\hline $\begin{array}{l}\text { Consumption } \\
\text { (g/head/day) }\end{array}$ & $1056.25 \pm 1.45^{\mathrm{ns}}$ & $975 \pm 95.74^{\mathrm{ns}}$ & $1085 \pm 61.91^{\mathrm{ns}}$ & $1070.5 \pm 87.17^{\mathrm{ns}}$ \\
\hline Feed Conversion & $47.34+10.32^{\mathrm{ns}}$ & $40.94 \pm 8.24^{\mathrm{ns}}$ & $44.83 \pm 8.017^{\mathrm{ns}}$ & $42.36+5.80^{\mathrm{ns}}$ \\
\hline
\end{tabular}

*Note: H0: control, H1: 10\% turmeric; H2: 10\% Ginger, H3 (5\% ginger $+5 \%$ turmeric) ; ns = not significant effect $(\mathrm{P}>0.05) ; \mathrm{a}, \mathrm{b}=$ significant $(\mathrm{P}<0.05)$

\subsection{Consumption}

That nutrient requirements for livestock between species and different physiological ages. The amount of rations consumed by livestock must be adjusted to the livelihoods and weights of the animals. In this study ration was calculated from $10 \%$ of the body weight of the sheep. This is in accordance where the need for dry ingredients rations for sheep body weight of $17.3 \mathrm{~kg}$ is calculated from $4 \%$ of the body weight of sheep [5]. Feed consumption with the addition of turmeric, ginger or its combination in block minerals was not significant $(\mathrm{P}>0.05)$ affecting feed consumption. The given of turmeric flour in the form of block feed has not affected the total ration consumption due to the frequency of block licking that is not the same between treated animals. Animals with sufficient mineral status will reduce their mineral consumption. Therefore, the treatment of adding turmeric to the block feed has not been able to increase feed consumption so that the curcumin contained in turmeric is less effective in influencing the appetite of livestock. The curcumin in turmeric has the effect of being able to influence appetite and expedite bile secretion, and ginger has a heat effect on the body that prevents the accumulation of gas in the digestion so that the digestion process can be more perfect [6]. This is in accordance with the opinion where ration consumption in livestock can be influenced by livestock factors on feed and environmental factors [7].Consumption of MBH Block feed is non-conventional feed for ruminants, in which there are various kinds of feed ingredients packaged in blocks. The addition of turmeric flour in the form of unrealized block feed $(\mathrm{P}>$ 0.05 ) affected the consumption of $\mathrm{MBH}$. The initial weight of block feed given to each livestock for 45 research days was approximately $5000 \mathrm{~g}$ with the average consumption of MBH at H0; namely $174.58 \mathrm{~g} /$ head/day, H1; as much as $185.83 \mathrm{~g} / \mathrm{head} /$ day, H2; $163.54 \mathrm{~g} /$ head/day and H3 ;173.75 g/head/day. The normal limit of consumption of turmeric which can reduce cholesterol is $10.6 \mathrm{~g} / \mathrm{head} /$ day [8]. Consumption of feed without the addition of turmeric flour is higher than $\mathrm{H} 1$ (10\% ginger) and $\mathrm{H} 2$ (5\% ginger and 5\% turmeric) in block minerals. This is caused by the block feed does not contain turmeric which can cause a distinctive odor from essential oils in turmeric, as well as zingiber in ginger. The smell of stinging turmeric and bitter taste in MBH resulted in low consumption in H1. In addition, the difference in consumption / MBH lick is also thought to be influenced by the mineral status of the animal. For animals that have fulfilled their mineral status, the consumption of MBH (including turmeric in it) will drop. As a result, 
MBH will be consumed intensively if the sheep are in need of minerals. This causes the consumption of $\mathrm{MBH}$ and the dry ingredients of the diet to vary depending on the mineral status of the animal.

\subsection{Average Daily Gain}

Daily body weight gain gave significant results $(\mathrm{P}<0.05)$ in $\mathrm{H} 1, \mathrm{H} 2$ and $\mathrm{H} 3$. The highest ADG was achieved in the MBH treatment with a combination of adding 5\% turmeric and 5\% ginger. This means that with the addition of herbal turmeric, ginger or a combination thereof in block minerals can affect body weight gain.

Body weight gain is interpreted as the ability to convert nutrient substances contained in feed into meat [9]. The addition of turmeric in the form of block feed was significantly different $(\mathrm{P}<0.05)$ with an increase in the daily average. This is because consumption in all treatments is also not significantly different. Body weight gain is influenced by several factors including total nutrient consumption obtained every day, type of livestock, age, genetic condition, environmental conditions of each individual and management [5].

The average daily body weight gain of sheep in this study was $23-25.55 \mathrm{~g} / \mathrm{head} / \mathrm{day}$. This result is lower than the research in sheep that consumed complete ration feed plus $1 \%$ turmeric in $\mathrm{Ca}$ soap from 21 lemuru fish oil containing nutrients according to sheep's needs resulting in daily body weight gain of $135 \mathrm{~g} /$ day [8]. The curcumin found in turmeric flour has the effect of being able to affect appetite. In addition, turmeric flour indirectly affects the consumption of rations and absorption of nutrients - which can ultimately be manifested in the form of meat production [6]. The synthesized proteins in the body are used as substances needed for growth and to maintain all body tissues [10].

Lack of nutrient intake in livestock affects the level of production and reproduction of livestock. The high meat production can be obtained if livestock have rapid growth with a good maintenance system [11]. Good maintenance produces an adult body size in a goat achieved at the age of one year, but if the condition of maintenance is not good then the adult body will be reached at more than one year of age.

\subsection{Feed Conversion Ratio}

Conversion of ruminant livestock rations is influenced by ration quality, digestibility value and efficiency of utilization of nutrients in metabolic processes in the body tissues of livestock. The better the quality of ration consumed by livestock, followed by weight gain, the ration conversion value will be lower and the more efficient the ration will be used [12]. The ration conversion can be used to increase the efficiency of a livestock business [13]. The addition of turmeric, ginger and its combination in the form of block feed was not significant $(\mathrm{P}>0.05)$ affecting the conversion of rations. The ration conversion value in the study showed a value that 
was higher than the ration conversion value for sheep in general so that the ration used in this study was less efficient. The ration conversion value in this study is 40.94-47.34.High ration consumption with low nutrient content followed by low body weight gain makes ration conversion value higher than conversion ration for ruminants in general. The conversion value of rations for goats and sheep in general is 4 [5]. The feed conversion was influenced by the amount of rations consumed and livestock activities. The factors that influence digestibility to improve efficiency of ration conversion are temperature, ration travel rate through digestion devices, physical form of rations, composition of rations and effects on the ratio of other nutrient substances [14]. Curcumin contained in turmeric flour can stimulate bile acid secretion, which is one of the basic ingredients of cholesterol [6].

Increased secretion of bile acids causes the cholesterol concentration in the blood to be reduced. The increased excretion of bile acids will stimulate the body, especially the liver, to synthesize new bile acids derived from cholesterol so that the overall cholesterol in the body decreases [15].

The amount of curcumin that can reduce cholesterol is $0.3 \mathrm{~g} /$ day. However, the curcumin consumed in this study was quite low at $0.06-0.12 \mathrm{~g} /$ day so that it was not effective in stimulating bile acid secretion [8].Feed given to sheep as experimental animals follows feed management found in research sites using feed that is below the standard requirements.

\section{Conclusion and Recommendation}

\subsection{Conclusion}

Based on palatability tests, $\mathrm{MBH}$ with turmeric $10 \% ; 10 \%$ ginger or a combination of $5 \%$ ginger and 5\% turmeric in the form of Herbal Minerals Block has a good palatability (preferred) and can improve the performance of local sheep

\subsection{Recommendation}

From the results of these studies, it can be suggested to examine the effect of these treatments on the health of sheep.

\section{Acknowledgments}

On this occasion, we would like to thanks to the Universitas Muhammadiyah Tapanuli Selatan and all those who assist in the implementation of this Research activity in 2018.

\section{REFERENCES}

[1] J. W. Purseglove, E. G. Brown, C. L. Green and S.R.J. Robins. Species. vol. 2. Longman, London and New York, 1981.

[2] M. W. Sidik, Moelyono and A. Muhtadi. "Temulawak (Curcuma xanthoriza, Roxb.) Pengembangan dan Pemanfaatan Obat Bahan Alam" Phytomedica, 1995. 
[3] T. Sutardi, Landasan Ilmu Nutrisi. Diktat Kuliah.Fakultas Peternakan. Bogor: Institut Pertanian Bogor, 1980.

[4] B. Haryanto. "Pakan domba dan kambing," Proseding Sarasehan Usaha Ternak Domba dan Kambing Menyongsong Era PJPT II. Balai Penelitian Ternak, Ciawi. 1992.

[5] National Research Council. Nutrient Requirement of Sheep. National. Academy Press, Washington. 2006.

[6] Arifin and Kardiyono. "Temulawak dalam pengobatan Tradisional". Proseding Simposium Nasional Temulawak. Lembaga penelitian Universitas Pajajaran. Bandung. pp. 210-219, 1985.

[7] Arora, Pencernaan Mikrobia pada Ruminansia. Gadjah Mada. Yogyakarta: University Press, 1989.

[8] A. Sudarman and D. A. Astuti, Pemberian sabun-Ca dari minyak lemuru dengan penambahan aroma herbal untuk produksi daging domba dan susu kambing rendah kolestero. Laporan Penelitian. Bogor: Institut Pertanian Bogor, 2007.

[9] E. Tillman, H. Hartadi, S. Reksohadiprojdo and S. Lebdosoeharjo. Ilmu Makanan Ternak Dasar. Yogyakarta: Gadjah Mada University Press, 1998.

[10] W. G. Pilliang and S. Djojosoebagio, Fisiologi Nutrisi. vol. 1 dan 2. Bogor: Institut Pertanian Bogor Press, 2006.

[11] T. N. Edey. Tropical Sheep and Goat Production. Australia University International. Canberra. 1983.

[12] W. G. Pond, D. C. Church and K. R. Pond. Basic Animal Nutrition and Feeding. 4Th Ed, John Wiley and Sons Press, New York, 1995.

[13] M. C. Nesheim, R. E. Austic and L. E. Card. Poultry Production. Lea and Febiger, Philadelphia. 1979.

[14] R. Anggorodi, Ilmu Makanan Ternak Umum. Jakarta: PT Gramedia, 1994.

[15] W. Pujiastuti. "Pengaruh Pemberian Temulawak (Curcuma Xanthorriza, Roxb) dan Minyak Kelapa Dalam Ransum Terhadap Kadar Lemak Dan Kolesterol Telur," Seminar Nasional Teknologi Peternakan dan Veteriner. Balai Penelitian Ternak, Bogor, 2001 